\title{
OCORRÊNCIA DE COLIFORMES FECAIS E RESISTÊNCIA A ANTIBIÓTICOS EM ÁGUA EMPREGADA PARA FINS DE DESSEDENTAÇÃO ANIMAL EM CURITIBANOS - SC
}

\section{OCCURRENCE OF FECAL COLIFORMS AND ANTIBIOTIC RESISTANCE IN WATER USED FOR ANIMAL DRINKING PURPOSES IN CURITIBANOS - SC}

\author{
Gabrielle França Ribeiro ${ }^{1}$ \\ Júlia Elizabeth Proença ${ }^{2}$ \\ Natalia Maria Martinazzo Angelo ${ }^{3}$ \\ Sonia Purin da Cruz ${ }^{4}$
}

Submetido: 27/03/2021 / Aprovado: 28/10/2021 / Publicado: 30/11/2021.

\begin{abstract}
Resumo
O consumo de água contaminada gera sérios problemas de saúde em populações humanas e também na produção animal das regiões rurais. Paralelamente, a ingestão de microrganismos resistentes a antibióticos, ou seja, que sobrevivem ao tratamento com determinados antibióticos, deve ser cuidadosamente considerada sob o ponto de vista de saúde única. Nesse sentido, os objetivos do presente trabalho foram: 1) avaliar a qualidade microbiológica da água e sua conformidade para consumo animal em propriedades rurais de Santa Catarina, e 2) avaliar a resistência antimicrobiana de isolados de Escherichia coli. A quantidade de coliformes fecais foi determinada pela técnica de tubos múltiplos, e utilizada para definir a classe de qualidade e uso da água, com base em resoluções federais. A resistência a antimicrobianos foi estudada por antibiograma, com o método de difusão por disco. Cinco das 15 propriedades apresentaram valores de coliformes fecais acima do limite permitido para consumo animal. Porém, a resistência antimicrobiana foi detectada em resposta a maioria dos antibióticos testados: ampicilina (19,7\%), tetracicilina $(17,85 \%)$ e ampicilina+sulbactam (1,78\%). Nenhum isolado de E. coli foi resistente a ciprofloxacino. Esses dados obtidos alertam para a importância do tratamento de água, bem como da preservação de recursos hídricos em geral, para minimizar efeitos negativos da ocorrência de doenças em animais e evolução da multirresistência.
\end{abstract}

Palavras-chave: Resistência antimicrobiana. Escherichia coli. Qualidade de água. Antibiograma.

\footnotetext{
Abstract

Consumption of contaminated water leads to serious health problems in human populations and also in animal production at rural areas. Likewise, ingestion of antibiotic-resistant microorganisms, i.e., that survive treatment with certain antibiotics, must be carefully considered under the scope of

${ }^{1}$ Graduanda do Curso de Medicina Veterinária da Universidade Federal de Santa Catarina (UFSC) - Campus de Curitibanos. E-mail: gabriellefrancaribeiro@gmail.com

${ }^{2}$ Graduanda do Curso de Engenharia Florestal da Universidade Federal de Santa Catarina (UFSC) - Campus de Curitibanos. E-mail: juh2206@gmail.com

${ }^{3}$ Graduanda do Curso de Engenharia Florestal da Universidade Federal de Santa Catarina (UFSC) - Campus de Curitibanos. Vínculo Institucional. E-mail: nmmartinazzo@gmail.com

${ }^{4}$ Ph.D. em Ciências do Solo e Vegetal pela West Virginia University, Estados Unidos. Professora de Microbiologia da Universidade Federal de Santa Catarina (UFSC) - Campus de Curitibanos. E-mail: s.purin@ufsc.br DOI: http://dx.doi.org/10.24021/raac.v19i1.6217 (c) (i) $(9)$ 
one health. Hence, the goals of this study were: 1) to evaluate microbiological quality of water and its conformity for animal consumption in farms at Santa Catarina, and 2) to evaluate antimicrobial resistance of Escherichia coli isolates. The quantity of fecal coliforms was determined by the multiple tubes technique, and used to define class and use of water, based on federal regulations. Resistance to antimicrobials was studied through antibiogram, with the disk diffusion method. Five of 15 properties presented values of fecal coliforms above the limit allowed for animal consumption. However, antimicrobial resistance was detected in response to the majority of tested antibiotics: ampicillin (19.7\%), tetracycline (17.85\%) and ampicillin+sulbactam $(1.78 \%)$. No isolate of $E$. coli was resistant to ciprofloxacin. These data raise attention to the importance of water treatment, as well as preservation of water resources in general, to minimize the negative effects from occurrence of animal diseases and evolution of multiresistance.

Keywords: Antimicrobial resistance. Escherichia coli. Quality of water. Antibiogram.

\section{INTRODUCTION}

Water is one of the most important resources for all life forms on the planet, and thus conservation of ocean, rivers, lakes and aquifers demands responsiveness from population, government and society. Records from the United Nations show that $80 \%$ of worldwide-consumed water returns to the environment without any type of treatment (UN WWAP, 2017). Hence, bodies of water constantly receive contaminants such as pesticides, heavy metals, herbicides, antibiotics and microorganisms (SIGMAN, 2002; MENA-RIVERA and JOSÉ QUIRÓS-VEGA, 2018; MEYER et al., 2019; SYAFRUDIN et al., 2021).

Within microbial contaminants, total and fecal coliforms are the most frequent group of biological indicators used to assess water quality (ASHBOLT et al., 2001; GOSHU et al., 2021). The incidence of fecal coliforms in water (i.e., Escherichia coli) signifies water pollution by animal or human feces, which is strongly related to pathogenic protozoan, fungi, viruses and other bacteria, as well (MASSE et al., 2010; SINGH et al., 2021). Thus, water with fecal coliforms must not be used for drinking purposes without previous treatment, once several diseases may be transmitted. However, other water contaminated with fecal coliforms may be applied to crop irrigation, fishing, sports and recreation, or also animal drinking.

In Brazil, federal legislation establishes five categories of water use based on levels of pollutants (BRASIL, 2005). Regarding fecal coliforms, animals can drink water that contains up to $1,000 \mathrm{UFC} \mathrm{mL}^{-1}$, which is the limit for water classified as Special or Types 1, 2 and 3. Even though this concentration of coliforms is thought to be considered safe for animals, because it should not lead to animal sickness or death, coliforms may exhibit genes for antibiotic resistance. This aspect is not taken into account by any governmental health or environmental agency, although it has serious short and long term effects on animals and humans.

After being ingested through water, coliforms may colonize intestinal sites or share resistance genes with bacteria from intestinal microbiome by conjugation (MISHRA et al., 2018). Thus, populations of antibiotic-resistant bacteria in the animal's body are disseminated in the environment by defecation (YANG et al., 2016, ZHANG et al., 2021). Coliforms are able to move from feces to soil and be carried to plants and lakes, ponds or rivers, mainly due to surface runoff (VANDERZAAG et al., 2010). As a result, surface and underground water bodies get increased microbiological contamination by antibiotic-resistant bacteria. Therefore, if animals drink water that exceeds coliform limits, they have higher chances of developing serious diseases, and also contribute to environmental pollution through contaminated feces. 
Increased frequency of drug-resistant microorganisms in the environment also represents a threat to human health, because is strongly related to diseases that cannot be treated with antibiotics (STREICHER, 2021). As a first stage, bacteria are transported by rain from animal feces to soil or plants that are consumed raw, such as lettuce and carrots (HA et al., 2010; VANDERZAAG et al., 2010). Without proper sanitization, coliforms will be ingested and contribute to spread resistance genes in the human body (WALIA et al., 2011). Consumption of untreated water, which is often observed in farms and rural neighborhoods, also leads to coliform ingestion and multiplication. When an infection is developed, treatment with several types of antibiotics will be challenging, expensive and sometimes impossible, leading to death.

As a matter of fact, 700,000 people die due to infections caused by antibiotic-resistant bacteria worldwide, every year. Projections from the World Health Organization indicate that this will be the major cause of deaths in the entire world by 2050 (BONECA, 2021). Therefore, for the past few years, international agencies have proposed robust "One Health Approaches" in order to minimize dissemination of antibiotic-resistant bacteria through the environment (HERNANDOAMADO et al., 2019; KIM and CHA, 2021). In this sense, monitoring water quality used for animal drinking purposes is a key (but still neglected) aspect. In Brazil, for example, cattle population amounted to about 222 million head in 2020, the largest cattle inventory in the world. This can represent a major source of microbiological pollution if water used for animal drinking has poor quality and drug-resistant microorganisms. Hence, the goals of this study were: 1) To evaluate microbiological quality of water used for animal drinking by quantifying fecal coliforms in 15 farms in Brazil; 2) To assess antibiotic resistance in isolates of fecal coliforms (Escherichia coli).

\section{MAterial AND MethodS}

\subsection{Study area and sampling process}

This study was carried on in the city of Curitibanos - SC $\left(27^{\circ} 16^{\prime} 44^{\prime \prime} \mathrm{S}\right.$ and $50^{\circ} 34^{\prime} 57^{\prime \prime} \mathrm{W}$, in July 2020). Fifteen sampling sites were chosen throughout the city, in small farms where animals drink untreated water (Figure 1). Details about each farm, regarding type and number of animals, as well as water source, are shown in Table 1. No physical or chemical treatment of water, prior to animal drinking, was reported to be performed at any of the fifteen properties.

Figure 1. Image of Santa Catarina state (Brazil) and Curitibanos, city where research was performed. Number from 1 to 15 represent farms from which water samples were obtained. Source: Adapted from Google Earth. 


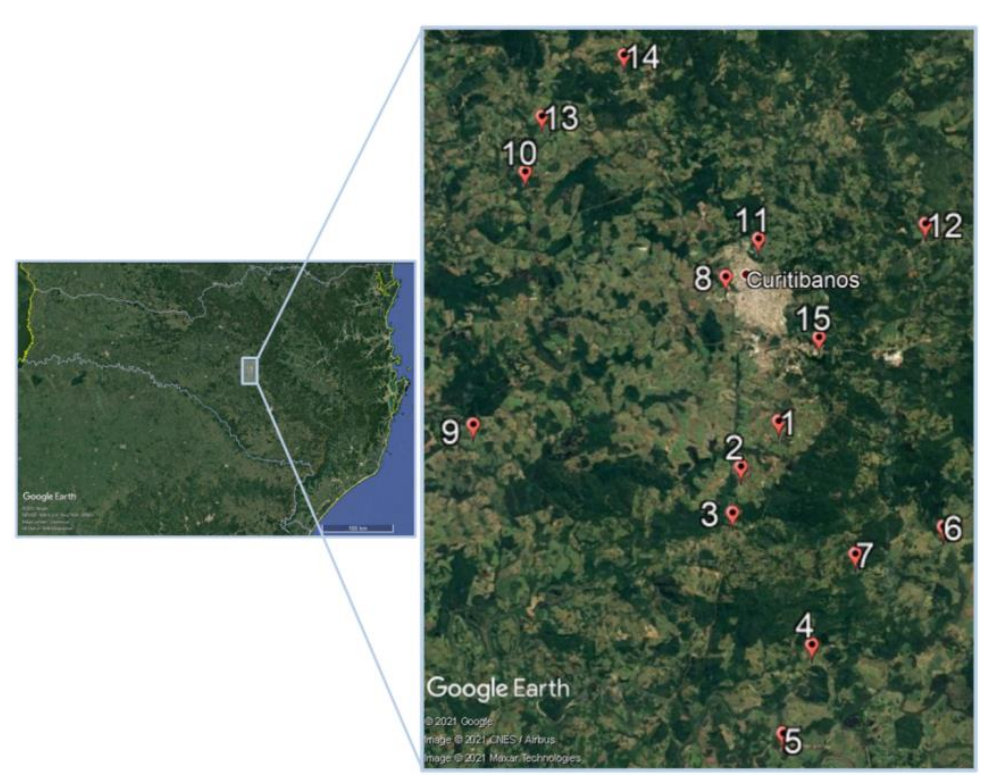

Table 1. Information about farms where water samples were obtained. Curitibanos - SC, 2021.

\begin{tabular}{cccc}
\hline Site & Location & Water source & Animals \\
\hline 1 & SC-120 & Pond & 20 sheep \\
2 & SC-120 & Pond & 11 sheep, 3 equine \\
3 & SC-120 & River & 30 swine, 10 cattle \\
4 & Horizolândia & Pond & 50 cattle \\
5 & Horizolândia & Pond & 20 swine \\
6 & Rio Cachorros & River & 9 cattle \\
7 & Horizolândia & Pond & 2 cattle \\
8 & São Francisco & Stream & 2 cattle \\
9 & Capão da Mortandade & Well & 45 cattle \\
10 & Marombas & Well & 20 cattle \\
11 & Lagoinha & Pond & 20 cattle \\
12 & Estrada Velha & Pond & 6 cattle, 3 sheep \\
13 & Marombas & Pond & 30 cattle \\
14 & Marombas & Pond & 10 cattle \\
15 & Universitário & Pond & 4 sheep \\
\hline
\end{tabular}

All samples were collected within a same day. In each site, one composite sample of $100 \mathrm{~mL}$ was obtained from three individual samples. Samples were taken from places were animals usually reach water to drink (several centimeters from the shore).

Sampling procedures followed orientations from a Federal Agency in Brazil (BRASIL, 2013). Pre-sterilized flasks containing 10\% sodium thiosulfate were used for field sampling. All flasks were kept in styrofoam boxes with ice until analyses were conducted in laboratory conditions at the Federal University of Santa Catarina (Campus Curitibanos - SC). 


\subsection{Number of coliforms}

Fecal coliforms were quantified by the Multiple-Tube Fermentation technique, following international and national standards (WHO, 1996; BRASIL, 2013).

Water samples were first inoculated into nine tubes with Lauryl Tryptose Broth, each one containing a small Durham tube. Three tubes, with $10 \mathrm{~mL}$ double-strength medium, were inoculated with $10 \mathrm{~mL}$ of water (dispensed with pre-sterilized glass pipettes). Other three tubes, with $10 \mathrm{~mL}$ single-strength medium, were inoculated with $1 \mathrm{~mL}$ of water. In the remaining three tubes, also with $10 \mathrm{~mL}$ single-strength broth, an aliquot of $0.1 \mathrm{~mL}$ was inoculated. Incubation was performed at $35.0^{\circ} \mathrm{C}$ for 48 hours. Positive tubes were considered those with microbial growth and fermentation (detected based on gas production in Durham tubes).

Each positive Lauryl Tryptose tube was used to inoculate a tube with EC broth. Durham tubes were also used, in order to detect fermentation produced by fecal coliforms. Incubation lasted 24 hours, at $44.5^{\circ} \mathrm{C}$. The number of positive tubes, originated from each tube in the dilution series, was determined and used to calculate the MPN - Most Probable Number $100 \mathrm{~mL}^{-1}$.

\subsection{Classification of water quality}

In Brazil, federal legislation establishes several physical, chemical and microbiological parameters that categorize water in 4 classes (BRASIL, 2005). Each class has a specific use, based on its quality. Water can be used for animal drinking purposes if levels of coliforms are below $1,000100 \mathrm{~mL}^{-1}$. This would be observed in Class $1(<200), 2$ or $3(<1,000)$.

Based on the MPN of fecal coliforms, water from each site was classified as "in conformity or not" with water standards established regarding animal ingestion (BRASIL, 2005).

\subsection{Evaluation of antibiotic resistance}

From each water sample analyzed, one EC tube was used to inoculate Petri Dishes with MacConkey Agar and obtain single colonies. Petri Dishes were incubated at $36^{\circ} \mathrm{C}$ for 24 hours.

In order to test antimicrobial resistance, four colonies from each Petri Dish were chosen (BORTOLOTI et al., 2018). Each colony was inoculated into a tube containing Mueller Hinton broth, and kept at $35^{\circ} \mathrm{C}$ overnight. These conditions produce an inoculum with a $0.5 \mathrm{McF}$ arland Standard equivalent (NCCLS, 2003).

Antibiotic resistance was evaluated based on the Kirby-Bauer Disk Diffusion Susceptibility Test Protocol (NCCLS, 2003). In this assay, inoculum was spread on the surface of Mueller Hinton Agar in Petri Plates with a sterile swab. In each plate, 4 disks of antibiotics were introduced with pre-sterilized tweezers. Four antibiotics were tested: ampicillin, ciprofloxacin, tetracycline and ampicillin+sulbactam. Those represent class A, B, C and D for treatment of infections with Enterobacteriaceae, as recommended by health agencies in Brazil in standard protocols (LABORCLIN, 2019).

Control plates were inoculated with Escherichia coli ATCC $^{\circledR}$ 25922, a strain that is recommended for quality control (NCCLS, 2003), and obtained from American Type Culture Collection.

Plates were kept at $35^{\circ} \mathrm{C}$ for 16 hours. Inhibition zone was measured around each antibiotic disk. Values were compared to standard ranges that define bacteria as sensitive, intermediate or resistant to each drug (LABORCLIN, 2019). 


\section{RESULTS AND DISCUSSION}

One third of studied farms had water with coliform contamination in high values, such that its use for animal drinking is not recommended. In only one place, water was free from bacteria. The M.P.N. of fecal coliforms, as well as classification of water, are shown in Table 2.

Table 2. Most Probable Number (M.P.N.) of fecal coliforms and corresponding classification of water obtained from 15 farms in Curitibanos, SC.

\begin{tabular}{cccc}
\hline $\begin{array}{c}\text { Sampling } \\
\text { site }\end{array}$ & $\begin{array}{c}\text { Fecal coliforms } \\
\text { (M.P.N. 100 } \mathbf{~ m}^{-\mathbf{1}} \text { ) }\end{array}$ & Class & $\begin{array}{c}\text { Conformity for } \\
\text { animal drinking }\end{array}$ \\
\hline 1 & 460 & $2 / 3$ & Yes \\
2 & $>1,100$ & 4 & No \\
3 & 240 & $2 / 3$ & Yes \\
4 & 460 & $2 / 3$ & Yes \\
5 & 1,100 & 4 & No \\
6 & 460 & $2-3$ & Yes \\
7 & 1,100 & 4 & No \\
8 & $>1,100$ & 4 & No \\
9 & 43 & 1 & Yes \\
10 & Absent & 1 & Yes \\
11 & 11 & 1 & Yes \\
12 & 1,100 & 4 & No \\
13 & 240 & $2-3$ & Yes \\
14 & 21 & 1 & Yes \\
15 & 240 & $2-3$ & Yes \\
\hline
\end{tabular}

A total of 56 isolates (4 isolates from 14 farms) were obtained. Percentage of isolates classified as sensitive, intermediate and resistant are presented in Figure 2. The highest value of antibiotic resistance was observed against ampicillin (19.70\%), followed by tetracycline $(17.85 \%)$ and ampicillin+sulbactam (1.78\%). Ciprofloxacin was the only drug against which bacteria did not reveal resistance. On average, 8.9 and $1.8 \%$ of isolates classified as intermediate were observed with ampicillin and ampicillin+sulbactam, correspondingly. 
Figure 2. Percentage of fecal coliforms isolates classified as resistant, intermediate or sensitive to ampicillin, ampicillin+sulbactam, ciprofloxacin and tetracycline. Isolates were obtained from water used for animal consumption in farms at Curitibanos - SC, Brazil.

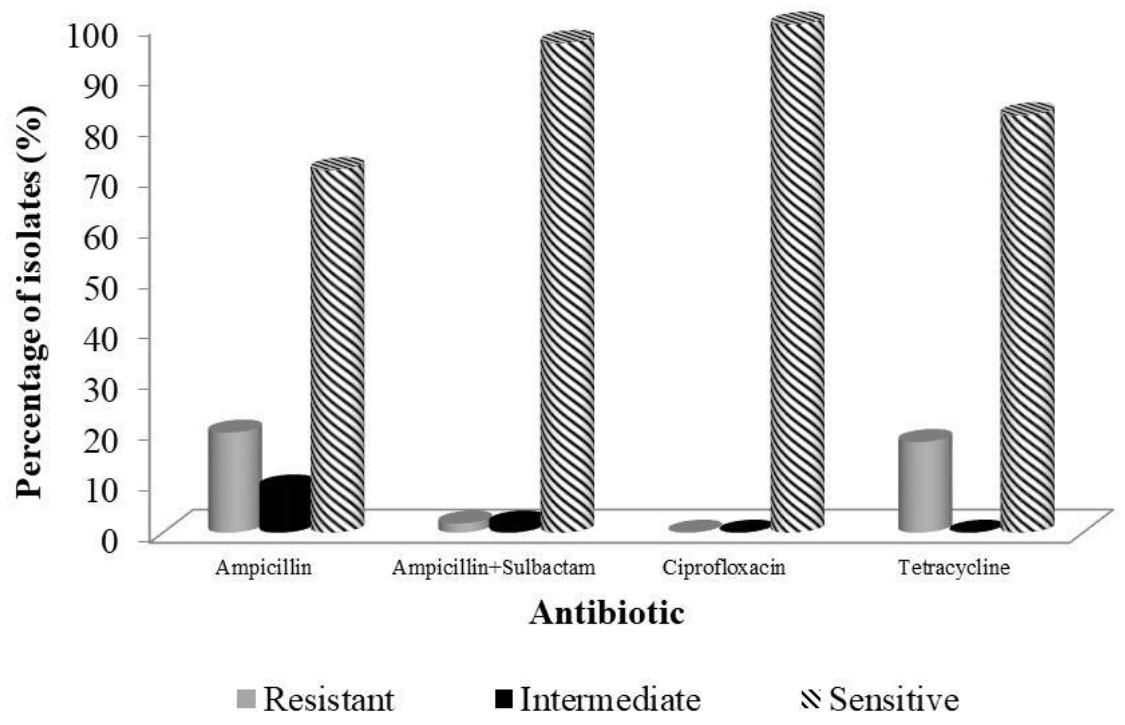

In Figure 3, isolates are classified according to the number of tested antibiotics to which they were resistant (no matter its type). Data reveal that 9 out of 54 bacterial isolates (16.07\%) were resistant to only one antibiotic. Furthermore, 6 isolates $(10.71 \%)$ exhibited resistance to two antibiotics. No isolate was resistant to three or four antibiotics simultaneously. 
Figure 3. Percentage of fecal coliform isolates that are classified as resistant to $1,2,3$ or 4 antibiotics simultaneously. Isolates were obtained from water used for animal consumption in farms at Curitibanos - SC, Brazil.

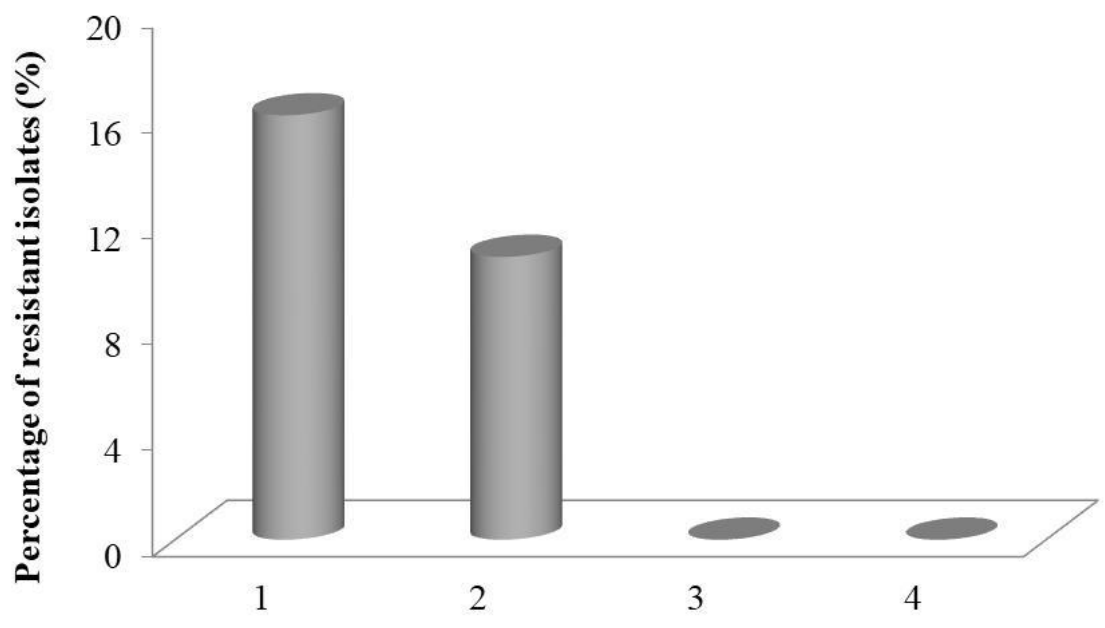

Number of antibiotics

Water used for animal drinking has direct impacts on animal health, as well as on environmental quality. High concentrations of microorganisms in ingested water result in more contaminated feces that are eliminated in soil and return to the environment (JAHNE et al., 2015). Therefore, monitoring water that is used for animal consumption is a key component of one-health approaches (MAZERI et al, 2021).

In this study, $33 \%$ of farms presented water with microbiological contamination above recommended by federal laws in Brazil. Other researchers have also monitored coliform quantities in different States and observed high levels of contamination, classifying water as unsuitable.

One of the first studies in Brazil was carried on in São Paulo, and showed that $12.4 \%$ of 113 sampled sites had coliform levels above the allowed limit (SOUZA et al., 1992). Toledo et al. (2017) evaluated presence of fecal coliforms in 124 water samples from dairy farms in Paraná. On average, $44 \%$ of sites were contaminated with fecal coliforms. Castro et al. (2019) studied water used for small ruminants in 23 farms, and observed that fecal coliforms were present at levels between $<1.8$ and $>1.6 \times 10^{3} 100 \mathrm{~mL}^{-1}$ in nearly $74 \%$ of sampled sites.

Assessment of coliforms has also been investigated in other countries. In Canada, Masse et al. (2010) detected total and fecal coliforms in over $90 \%$ of all studied places, where water was used to the animals on dairy farms. In Slovak, Sasakova et al. (2018) quantified fecal coliforms in ground water through 4 seasons in 6 farms, where water was consumed by cattle and horse. Data from spring season revealed that $50 \%$ of sites were contaminated with E. coli in levels above limits established by Government Regulations. In the remaining 3 seasons, concentrations of $E$. coli exceeded this limit at $67 \%$ of sites. In Chile, Valenzuela et al. (2012) observed that contamination of a well, used for animal drinking, occurred in every month of the year. In addition, no sample attended legal requirements for animal drinking. 
Altogether, these studies emphasize the poor microbiological quality of water used by animals worldwide. Government regulations seem not to be respected in most cases. For instance, in Canada, there are no definite guidelines for the presence of microbes in livestock drinking water sources, but some reports suggest that total coliforms should be $<5,000100 \mathrm{~mL}^{-1}$. In Slovak, according to the SR Government Regulations No. 296/2005, E. coli concentration must not exceed $2,000 \mathrm{~mL}^{-1}$. In Chile, E. coli must be absent and total coliforms cannot exceed $500 \mathrm{UFC} \mathrm{mL}^{-1}$ for both human and animal consumption (CHILE, 2005). In the United States, the Environmental Protection Agency recommends that water used for livestock contains less than 5,000 coliforms $100 \mathrm{~mL}^{-1}$, whereas fecal coliforms must not be present (APHA et al., 2012).

Water with high numbers of coliforms will, in fact, result in feces with more microorganisms, which will be transported by rain precipitation and cause pollution of other rivers and wells. In Canada, a study with more than 56,000 wells showed that occurrence of $E$. coli is strongly associated with precipitation and animal density (INVIK et al., 2019). In Chile, Valenzuela et al. (2009) worked with wells located in farming areas with cattle, and observed positive correlations between total coliforms, as well as E. coli, with precipitation.

Microbial contamination is sometimes so severe that can affect aquifers. Urseler et al. (2019) studied 62 samples of water from an aquifer in Argentina, and 8\% of samples were contaminated with E. coli. Strong correlations between microbiological contamination and land use were reported, mainly in areas where high animal populations and wastewater treatment infiltration were reported.

This is, as far as we are concerned, the first study worldwide to classify water according to coliform concentration and evaluate antibiotic resistance in fecal coliforms. Therefore, direct comparisons regarding percentage of antibiotic resistance cannot be done with other studies. However, a few publications regarding antibiotic resistance in coliforms from water used by animals are found in the literature. In Brazil, Schneider et al. (2009) studied antibiotic resistance of E. coli isolates in a region of pig breeding. From the 205 isolates, 36.1\% were resistant to ampicillin, 27.8 to tetracycline, and $1.95 \%$ to ciprofloxacin. These average numbers are higher than those here reported, probably due to the extensive use of antibiotic in areas of pig production, what triggers development of antibiotic resistance. Parveen et al. (2005) evaluated water from ponds in dairy and beef cattle in Florida. Resistance to ampicillin was detected in 43 and $37 \%$ of isolates from farms with dairy and beef cattle, correspondingly. Concerning tetracycline, these numbers were 26 and 20\%. Faria et al. (2016) assessed occurrence of coliforms and antibioticresistance genes in 9 ponds and lakes from a zoo with birds, reptiles, and mammals. Concentration of fecal coliforms ranged from $5.5 \times 10^{3}$ to $3.6 \times 10^{6} \mathrm{UFC} \mathrm{mL}^{-1}$. On average, $67 \%$ of water samples presented genes of resistance to ampicillin, whereas no water sample had a positive result for tetracycline-resistance genes. An overall view of these reports will clearly point to high occurrence of either antibiotic-resistant bacteria or genes, both considered hazardous for animal health.

Other investigations were performed about antibiotic resistance in water from ponds and lakes, but those were not specifically used for animal drinking (i.e., irrigation, human consumption, fishing, and other destinations). Olowe et al. (2008) documented that 91.6 and $86.7 \%$ of E. coli isolates were resistant to ampicillin and tetracycline. Carnelli, Mauri and Demarta (2017) also verified high level of resistance to ampicillin (68\%) and tetracycline (42\%) in fecal coliforms. Vasconcelos et al. (2010) described that 25.6 of $E$. coli isolates from a weir were resistant to tetracycline, and 4.7 to ciprofloxacin. No resistance was detected regarding ampicillin.

Overall, it may be observed that all aquatic environments studied contain strains of bacteria that are resistant to most studied drugs, and this represents an alarming fact. Water with antibiotic- 
resistant bacteria may be considered as a reservoir of genes that can be spread to animals, and contribute to several challenges to health treatments. Also, it increases the probability of dissemination of antimicrobial resistance through diverse environments. This negative effect represents one of the most challenging topics in one-health politics, and highlights the need for integrative and conservationist practices.

\section{CONCLUSION}

Water from most farms presented satisfactory coliform levels, but the occurrence of antimicrobial resistance has potential negative effects. Ampicillin and tetracycline were the two predominant antibiotics against which bacteria presented resistance and effectiveness of treatments based on those two drugs may be compromised.

\section{REFERENCES}

APHA, 2012. Standard methods for the examination of water and wastewater, $22^{\text {nd }}$ edition. Washington: American Public Health Association (APHA), American Water Works Association (AWWA) and Water Environment Federation (WEF), 2012.

ASHBOLT NJ, GRABOW WOK, SNOZZI, M. Indicators of microbial water quality. In: Fewtrell L, Bartram J. Water quality - guidelines, standards and health. Assessment of risk and risk management for water-related infectious disease. London: IWA Publishing, 2001. p. 289-316. BONECA IG. The Future of Microbial Drug Resistance. Microbial Drug Resistance, v. 27, n. 1, p. 1-2, 2021.

BORTOLOTI KCS, MELLONI R, MARQUES OS, CARVALHO BMF, ANDRADE MC. Qualidade microbiológica de águas naturais quanto ao perfil de resistência de bactérias heterotróficas a antimicrobianos. Engenharia Sanitária e Ambiental, v. 23, n. 4, p. 717-725, 2018.

BRASIL. Fundação Nacional de Saúde. Manual prático de análise de água. Brasília : Funasa, 2013. 150 p.

BRASIL. Ministério do Desenvolvimento Urbano e Meio Ambiente. Conselho Nacional do Meio Ambiente - CONAMA. 2005. Resolução no 357, de 17 de março de 2005. Dispõe sobre a classificação dos corpos de água e diretrizes ambientais para o seu enquadramento, bem como estabelece as condições e padrões de lançamento de efluentes, e dá outras providências Diário Oficial da República Federativa do Brasil, Brasília, DF, 18 de março de 2005.

CARNELLI A, MAURI F, DEMARTA A. Characterization of genetic determinants involved in antibiotic resistance in Aeromonas spp. and fecal coliforms isolated from different aquatic environments. Research In Microbiology, v. 168, n. 5, p. 461-471, 2017. 
CASTRO MSM, DE VASCONCELOS AM, FONTENELLE ROS, JULIÃO MSS, SOARES ATL, DA SILVA LC, DE SOUSA FJS, SILVEIRA RMF. Water quality of small ruminant production systems in the Brazilian semiarid region. Biological Rhythm Research (Online), v. 50, p. 1-12, 2019.

CHILE, Instituto Chileno de Normalización (INN). Norma chilena NCh 409/1. Agua potable parte 1: requisitos. Chile: Instituto Nacional de Normalización, 2005, p. 14.

FARIA ACS, GODOY I, SANCHES AAA, IGLESIAS GA, CANDIDO SL, DA PAZ RCR, NAKAZATO L, DUTRA V. Detection of resistance genes and evaluation of water quality at zoo lakes in Brazil. Ciência Rural, v. 46, n. 5, p. 860-866, 2016.

GOSHU G, KOELMANS AA, DE KLEIN JJM. Performance of faecal indicator bacteria, microbial source tracking, and pollution risk mapping in tropical water. Environmental Pollution, 276:116693, 2021.

HA NT, KITAJIMA M, HANG NV, MATSUBARA K, TAKIZAWA S, KATAYAMA H, OGUMA K, OHGAKI S. Bacterial contamination of raw vegetables, vegetable-related water and river water in Ho Chi Minh City, Vietnam. Water Science and Technology, v. 58, n. 12, p. 2403$11,2008$.

HERNANDO-AMADO S, COQUE TM, BAQUERO F, MARTÍNEZ JL. Defining and combating antibiotic resistance from One Health and Global Health perspectives. Nature Microbiology, v. 4, n. 9, p. 1432-1442, 2019.

INVIK J, BARKEMA HW, MASSOLO A, NEUMANN NF, CEY E, CHECKLEY S. Escherichia coli contamination of rural well water in Alberta, Canada is associated with soil properties, density of livestock and precipitation. Canadian Water Resources Journal, v. 44, n. 3, p. 248-262, 2019.

JAHNE MA, ROGERS SW, RAMLER IP, HOLDER E, HAYES G. Hierarchal clustering yields insight into multidrug-resistant bacteria isolated from a cattle feedlot wastewater treatment system. Environmental Monitoring and Assessment, 187:4168, 2015.

KIM DW, CHA CJ. Antibiotic resistome from the One-Health perspective: understanding and controlling antimicrobial resistance transmission. Experimental and Molecular Medicine, 2021. doi: 10.1038/s12276-021-00569-z. Epub ahead of print. PMID: 33642573.

LABORCLIN. Manual de Antibiograma. Pinhais: Laborclin Produtos Para Laboratórios Ltda., 2019. $54 \mathrm{p}$.

MASSE L, MASSÉ DI, TOPP E, SÉGUIN G, SCOTT A, ORTEGA LM, PARISEAU E. Microbial and Physico-Chemical Characteristics of Surface Water Sources Used on Dairy Farms in Ontario. Water Quality Research Journal of Canada, v. 45, n. 3, p. 287-294, 2010. 
MAZERI S, BURDON BAILEY JL, MAYER D, CHIKUNGWA P, CHULU J, GROSSMAN PO, LOHR F, GIBSON AD, HANDEL IG, BRONSVOORT BMD, GAMBLE L, MELLANBY RJ. Using data-driven approaches to improve delivery of animal health care interventions for public health. Proceedings of the National Academy of Sciences of the United States of America, 118(5):e2003722118, 2021.

MENA-RIVERA L, QUIRÓS-VEJA J. Assessment of drinking water suitability in low income rural areas: a case study in Sixaola, Costa Rica. Water Health, v. 16, n. 3, p. 403-413, 2018.

MEYER AM, KLEIN C, FÜNFROCKEN E, KAUTENBURGER R, BECK HP. Real-time monitoring of water quality to identify pollution pathways in small and middle scale rivers. Science of The Total Environment, v. 651, n. 2, p. 2323-2333, 2019.

MISHRA M, ARUKHA AP, PATEL AK, BEHERA N, MOHANTA TK, YADAV D. Multi-Drug Resistant Coliform: Water Sanitary Standards and Health Hazards. Frontiers in Pharmacology, 9:311, 2018.

NCCLS. Performance Standards for Antimicrobial Disk Susceptibility Tests; Approved Standard Eighth Edition. NCCLS document M2-A8 [ISBN 1-56238-485-6].

OLOWE AO, OKANLAWON BM, OLOWE RA, OLAYEMI AB. Antimicrobial resistant pattern of Escherichia coli from human clinical samples in Osogbo, south western Nigeria. African Journal Of Microbiology Research, v. 2, p. 8-11, 2008.

PARVEEN S, LUKASIK J, SCOTT TM, TAMPLIN ML, PORTIER KM, SHEPERD S, BRAUN $\mathrm{K}$, FARRAH SR. Geographical variation in antibiotic resistance profiles of Escherichia coli isolated from swine, poultry, beef and dairy cattle farm water retention ponds in Florida. Journal of Applied Microbiology, v. 100, n. 1, p. 50-57, 2006.

SASAKOVA N, GREGOVA G, TAKACOVA D, MOJZISOVA J, PAPAJOVA I, VENGLOVSKY J, SZABOOVA T AND KOVACOVA S. Pollution of Surface and Ground Water by Sources Related to Agricultural Activities. Frontiers in Sustainable Food Systems, v. 2:42, 2018.

SCHNEIDER RN, NADVORNY A, SCHMIDT V. Perfil de resistência antimicrobiana de isolados de Escherichia coli obtidos de águas superficiais e subterrâneas, em área de produção de suínos. Biotemas, v. 22, n. 3, p. 11-17, 2009.

SIGMAN H. International spillovers and water quality in rivers: do countries free ride? American Economic Review, v. 92, n.4, p. 1152-1159, 2002.

SINGH AK, BHARDWAJ SK, DEVI S. Microbiological status of drinking water sources and its relationship with human health in Solan, India. Environmental Monitoring and Assessment, 193:32, 2021. 
SOUZA LC, IARIA ST, PAIM GV. Salmonelas e coliformes fecais em águas de bebida para animais. Revista Saúde Pública, v. 26, n. 5, p. 321-327, 1992.

STREICHER LM. Exploring the future of infectious disease treatment in a post-antibiotic era: A comparative review of alternative therapeutics. Journal of Global Antimicrobial Resistance, v. 20, n. 24, p. 285-295, 2021.

SYAFRUDIN M, KRISTANTI RA, YUNIARTO A, HADIBARATA T, RHEE J, AL-ONAZI WA, ALGARNI TS, ALMARRI AH, AL-MOHAIMEED AM. Pesticides in Drinking Water-A Review. International Journal of Environmental Research and Public Health, v. 18, n. 2:468, 2021.

TOLEDO RD, MARTINS FD, FERREIRA FP, DE ALMEIDA JC, OGAWA L, DOS SANTOS HL, DOS SANTOS MM, PINHEIRO FA, NAVARRO IT, GARCIA JL, FREIRE RL. Cryptosporidium spp. and Giardia spp. in feces and water and the associated exposure factors on dairy farms. PLoS One, v.12, n4:e0175311, 2017.

UN WWAP (UNITED NATIONS WORLD WATER ASSESSMENT PROGRAMME). United Nations World Water Development Report 2017: Wastewater: An untapped resource. United Nations Educational, Scientific and Cultural Organization, 2017.

URSELER NL, BACHETTI RA, DAMILANO G, MORGANTE V, INGARAMO RN, SAINO V, MORGANTE CA. Calidad Microbiológica Y Usos Del Agua Subterránea En Establecimientos Agropecuarios Del Centro-Sur De Córdoba, Argentina. Revista Internacional De Contaminación Ambiental, v. 35, n. 4, p. 839-848, 2019.

VALENZUELA E, GODOY R, ALMONACID L, BARRIENTOS M. Calidad microbiológica del agua de un área agrícola-ganadera del centro sur de Chile y su posible implicancia en la salud humana. Revista Chilena de Infectologia, v. 29, n. 6, p. 628-634, 2012.

VALENZUELA M, MONDACA MA, CLARET M, PÉREZ C, LAGOS B, PARRA O. Assessment of the origin of microbiological contamination of groundwater at a rural watershed in Chile. Agrociencia, v. 43, n. 4, p. 437-446, 2009.

VANDERZAAG AC, CAMPBELL KJ, JAMIESON RC, SINCLAIR AC, HYNES LG. Survival of Escherichia coli in agricultural soil and presence in tile drainage and shallow groundwater. Canadian Journal of Soil Science, v. 90, p. 495-505, 2010.

VASCONCELOS FR, REBOUÇAS RH, EVANGELISTA-BARRETO NS, DE SOUSA OV, VIEIRA RHSF. Perfil de Resistência Antimicrobiana de Escherichia coli isoladas do Açude Santo Anastácio, Ceará, Brasil. Arquivos do Instituto Biológico, v. 77, n. 3, p. 405-410, 2010. 
WALIA SK, KAISER A, PARKASH M, CHAUDHRY GR. Self-transmissible antibiotic resistance to ampicillin, streptomycin, and tetracyclin found in Escherichia coli isolates from contaminated drinking water. Journal of environmental science and health. Part A, Toxic/hazardous substances and environmental engineering, v. 39, n. 3, p. 651-662, 2004.

WHO - World Health Organization and International Programme on Chemical Safety. (1996). Guidelines for drinking-water quality: vol. 2, Health criteria and other supporting information. Geneva, 1996. 990 p.

YANG Q, WANG R, REN S, SZOBOSZLAY M, MOE LA. Practical survey on antibioticresistant bacterial communities in livestock manure and manure-amended soil. Journal of Environmental Science and Health, Part B, v. 51, n. 1, p. 14-23, 2016.

ZHANG RM, LIU X, WANG SL, FANG LX, SUN J, LIU YH, LIAO XP. Distribution patterns of antibiotic resistance genes and their bacterial hosts in pig farm wastewater treatment systems and soil fertilized with pig manure. Science of the Total Environment, 758:143654, 2021. 